\title{
SPÓR O PODSTAWY LEGALNOŚCI INTERWENCJI LECZNICZEJ Z PERSPEKTYWY NIEMIECKIEJ DOKTRYNY I JUDYKATURY
}

\section{Wprowadzenie}

Legalność interwencji medycznej ukierunkowanej na cel leczniczy, przeprowadzonej zgodnie z zasadami wiedzy i sztuki medycznej, przez osobę o odpowiednich kwalifikacjach i za zgodą pacjenta od dawna nie budzi wątpliwości. Pojawiają się one raczej na płaszczyźnie ustaleń faktycznych w konkretnym przypadku. Polska doktryna prawa karnego nie dopracowała się jednak jednolitego poglądu na temat podstaw, ze względu na które zabieg leczniczy oceniany jest jako legalny. Są one poszukiwane na płaszczyźnie bądź to wtórnego, bądź pierwotnego wyłączenia bezprawności czynu. Wedle pierwszego założenia zabieg leczniczy wyczerpuje ustawowe znamiona czynu zabronionego, którego bezprawność zostaje uchylona na podstawie kontratypu ${ }^{1}$, a w świetle drugiego - zabieg

* Dr, Katolicki Uniwersytet Lubelski Jana Pawła II; e-mail: mkinga@kul.pl.

1 Za tą koncepcją opowiedzieli się m.in. W. Wolter, Nauka o przestępstwie, Warszawa 1973, s. 197-198; J. Śliwowski, Prawo karne, Warszawa 1979, s. 120-121, 153; K. Buchała, Prawo karne materialne, Warszawa 1989, s. 287-288; M. Cieślak, Polskie prawo karne. Zarys systemowego ujęcia, Warszawa 1994, s. 243; I. Zgoliński [w:] I. Zgoliński, I. Zduński, Okoliczności wytaczające bezprawność. Zarys problematyki, Bydgoszcz 2012, s. 70; M. Mozgawa [w:] M. Mozgawa (red.), Prawo karne materialne. Część ogólna, Warszawa 2016, s. 257; A. Grześkowiak [w:] A. Marek (red.), Prawo karne. Zagadnienia teorii i praktyki, Warszawa 1986, s. 134-135; P. Daniluk, Czynność lecznicza jako kontratyp, „Prawo i Medycyna” 2008, nr 2, s. 31 i nast.; J. Piórkowska-Flieger, M. Szwarczyk, Warunki dopuszczalności zabiegu leczniczego i eksperymentu medycznego w świetle nowej ustawy o zawodzie lekarza, "Rzeszowskie Zeszyty Naukowe. Prawo - Ekonomia" 1998, t. 23, s. 147-148; J. Duda, Transplantacja w prawie polskim. Aspekty karnoprawne, Kraków 2004, s. 126-128; J. Najda, Z problematyki legalności zabiegów lekarskich na tle okoliczności wyłaczających bezprawność czynu, „Przegląd 
leczniczy przeprowadzony lege artis nie realizuje znamion typu przestępstwa jako zachowanie zgodne $\mathrm{z}$ regułami ostrożnego postępowania $\mathrm{z}$ dobrem prawnym i służące jego ochronie ${ }^{2}$. Niedawno zasadność tej dyskusji zakwestionowali przeciwnicy rozróżniania dwóch poziomów legalności czynu - pierwotnej i wtórnej3. Podobna wymiana poglądów ma jeszcze dłuższą historię w doktrynie i judykaturze niemieckiej. Jest to dorobek ponad stuletni i wciąż poszerzany, któremu warto przyjrzeć się bliżej nie tylko ze względów czysto poznawczych, ale też w celu ustalenia, na ile racje podnoszone w sporze o podstawy legalności zabiegu leczniczego łączą się z konkretnym stanem prawnym, a na ile mają charakter uniwersalny oraz czy i jak można je odnieść do tytułowej dyskusji prowadzonej w piśmiennictwie polskim. Polska doktryna nawiązuje do niemieckiej myśli prawniczej w omawianym kontekście, ale czyni to głównie w ramach uzasadnienia tezy o pierwotnej legalności zabiegu leczniczego i krytyki

Prawa i Administracji" 1995, t. 32, s. 60; L. Gardocki, Prawo karne, Warszawa 2006, s. 128129; J.J. Warylewski, Prawo karne. Część ogólna, Warszawa 2015, s. 284; A. Marek, Prawo karne, Warszawa 2011, s. 181-182.

2 Za tą koncepcją opowiedzieli się m.in. A. Zoll, Odpowiedzialność karna za niepowodzenie w leczeniu, Warszawa 1988, s. 10-16; tenże, Zaniechanie leczenia - aspekty prawne, „Prawo i Medycyna" 2000, nr 5, s. 32, 168; W. Wróbel, A. Zoll, Polskie prawo karne. Część ogólna, Kraków 2010, s. 110-111, 167-168; S. Śliwiński, Polskie prawo karne materialne. Część ogólna, Warszawa 1946, s. 190-191; M. Filar, Lekarskie prawo karne, Kraków 2000, s. 94-95; tenże, Odpowiedzialność karna związana z nieterapeutycznymi czynnościami lekarskimi, „Prawo i Medycyna" 2000, nr 5, s. 59-60; E. Plebanek, Materialne określenie przestępstwa, Warszawa 2009, s. 202, 209-210; R. Kędziora, Odpowiedzialność karna lekarza w związku z wykonywaniem czynności medycznych, Warszawa 2009, s. 52-53; J. Giezek [w:] M. Bojarski, J. Giezek, Z. Sienkiewicz, Prawo karne materialne. Część ogólna i szczególna, M. Bojarski (red.), Warszawa 2015, s. 171; A. Liszewska, Odpowiedzialność karna za błąd w sztuce lekarskiej, Kraków 1998, s. 64, 70, 73-77, 83; T. Sroka, Odpowiedzialność karna za niewłaściwe leczenie. Problematyka obiektywnego przypisania skutku, Warszawa 2013, s. 30; T. Dukiet-Nagórska, Autonomia pacjenta a polskie prawo karne, Warszawa 2008, s. 16-17, 153; Ł. Pohl, Prawo karne. Wykład części ogólnej, Warszawa 2015, s. 264; R. Kubiak, Kontratyp dozwolonego eksperymentu w świetle teorii kolizji dóbr i optacalności społecznej, „Państwo i Prawo” 2005, z. 12, s. 67-68. Uściślić należy, że niektórzy z wymienionych autorów upatrują w zabiegu leczniczym zamachu na dobro prawne, a jego pierwotną legalność opierają wyłącznie na zachowaniu reguł ostrożnego postępowania, zob. M. Filar, Leczenie - sztuka czy rzemiosło? (nowe polskie lekarskie prawo karne), [w:] L. Tyszkiewicz (red.), Problemy nauk penalnych. Prace ofiarowane Pani Profesor Oktawii Górniok, Katowice 1996, s. 63; T. Sroka, Odpowiedzialność karna..., s. 33-34.

3 Zob. A. Złotek, Charakter prawny zabiegu leczniczego - zarys problemu, "Czasopismo Prawa Karnego i Nauk Penalnych" 2010, nr 2, s. 60-62; T. Kaczmarek, O kontratypach raz jeszcze, „Państwo i Prawo” 2009, z. 7, s. 97. 
koncepcji przeciwnej. Zatem być może tytułowy spór - nawet jeśli na gruncie niemieckim pozostaje sporem - z perspektywy polskiego systemu prawa ukazuje siłę lub słabość którejś ze stron podobnej dyskusji.

Niemiecka dyskusja na temat podstawy legalności interwencji leczniczej (Heileingriff) ${ }^{5}$ koncentruje się zasadniczo, podobnie jak w Polsce, wokół pytania: czy interwencja taka wyczerpuje istotę czynu zabronionego (Tatbestand $)^{6}$, na które rozbieżnych odpowiedzi udzielają dwie koncepcje zwane Rechtfertigungslösung i Tatbestandslösung. Pierwsza z nich - generalnie rzecz ujmując - odpowiada polskiej koncepcji wtórnej legalności zabiegu leczniczego, a druga - jego legalności pierwotnej. Przedmiotem sporu jest interwencja lecznicza o stopniu dolegliwości mieszczącym się co najmniej w ustawowej istocie uszkodzenia ciała z § 223 ust. 1 niemieckiego Kodeksu karnego ${ }^{7}$ o następującej treści: „Kto narusza ciało innej osoby albo powoduje u niej szkodę na zdrowiu, podlega karze pozbawienia wolności do 5 lat albo grzywnie" ${ }^{8}$. Przyjęta w doktrynie i judykaturze wykładnia tego przepisu wyklucza spod jego zakresu takie oddziaływanie na ludzki organizm, które nie przekracza stopnia nieznacznego ${ }^{9}$. O ile więc przedmiotem sporu między Rechtfertigungslösung i Tatbestandslösung

4 Zob. A. Zoll, Odpowiedzialność karna..., s. 10; A. Liszewska, Odpowiedzialność karna..., s. 84,88 .

5 Jest to termin używany zazwyczaj w omawianym kontekście przez niemiecką doktrynę, zob. P. Bockelmann, Strafrecht des Arztes, Stuttgart 1968, s. 62-63; R. Reniger, Strafrecht. Besonderer Teil. Delikte gegen die Person und die Allgemeinheit, München 2012, s. 104.

6 Pojęcie Tatbestand tłumaczone jest jako (ustawowa) istota czynu zabronionego, zob. Z. Jędrzejewski, Bezprawność jako element przestępności czynu. Studium na temat struktury przestępstwa, Warszawa 2009, s. 15, 23.

7 Strafgesetzbuch in der Fassung der Bekanntmachung vom 13. November 1998 („Bundesgesetzblatt” I S. 3322), das zuletzt durch Artikel 1 des Gesetzes vom 30. Oktober 2017 („Bundesgesetzblatt” I S. 3618) z późn. zm. (dalej: StGB).

8 § 223 ust. 1 StGB: „Wer eine andere Person körperlich mißhandelt oder an der Gesundheit schädigt, wird mit Freiheitsstrafe bis zu fünf Jahren oder mit Geldstrafe bestraft”.

9 Szerzej zob. R. Reniger, Strafrecht..., s. 101-104; H. Lilie [w:] B. Jähnke, H. Laufhütte, W. Odersky (red.), Strafgesetzbuch. Leipziger Kommentar, t. 16, Berlin 2005, s. 40-50; T. Fischer, Strafgesetzbuch mit Nebengesetzen, München 2014, s. 1541-1542; K. Kühl, M. Heger, Strafgesetzbuch. Kommentar, München 2014, s. 1083-1084; K. Ulsenheimer [w:] K. Ulsenheimer, E. Biermann, R.W. Bock, Arztstrafrecht in der Praxis, Heidelberg 2015, s. 352; G. Arzt, U. Weber, B. Heirich, E. Hilgendorf, Strafrecht. Besonderer Teil. Lerbuch, Bielefeld 2009, s. 162; A. Loose, Strafrechtliche Grenzen ärztlicher Behandlung und Forschung, Berlin 2003, s. 32-34; B. Tag, Der Körperverletzungstatbestand im Spannungsfeld zwischen Patientenautonomie und Lex artis, Berlin-Heidelberg 2000, s. 442. 
może być operacja chirurgiczna, o tyle nie będzie nim mierzenie ciśnienia czy lekkie opukiwanie, chociaż iniekcja nasuwa już wątpliwości ${ }^{10}$.

\section{Rechtfertigungslösung}

Koncepcja zwana Rechtfertigungslösung reprezentowana jest niezmiennie od ponad wieku przez niemieckie orzecznictwo i znajduje aprobatę części doktryny. Opiera się na założeniu, że interwencja lekarska, naruszająca integralność cielesną wyczerpuje ustawową istotę uszkodzenia ciała z § 223 StGB, niezależnie od jej leczniczego celu lub skutku i od zachowania reguł sztuki ${ }^{11}$. Wyłączenie bezprawności takiej interwencji następuje dopiero na płaszczyźnie okoliczności wyłączających bezprawność (Rechtfertigungsgrund). W omawianej sytuacji, za okoliczność taką uznawana jest prawnie skuteczna zgoda (Einwilligung) pacjenta ${ }^{12}$.

Początek linii orzeczniczej opartej na Rechtfertigungslösung upatruje się w wyroku Sądu Rzeszy z dnia 31 maja 1894 r. Sprawa dotyczyła koniecznej dla ratowania życia amputacji stopy dziecka, przeprowadzonej lege artis, ale wbrew sprzeciwowi ojca. W pierwszej instancji Sąd Krajowy w Hamburgu w wyroku z dnia 2 lutego 1894 r. uznał, że udany i prawidłowo przeprowadzony zabieg nie może być uznany za uszkodzenie ciała,

10 Zob. R. Reniger, Strafrecht..., s. 104; A. Loose, Strafrechtliche..., s. 32-34.

11 Zob. A. Eser, Zur Regelung der Heilbehandlung in rechtsvergleichender Perspektive, [w:] T. Weigend (red.), Festschrift für Hans Joachim Hirsch zum 70. Geburtstag am 11. April 1999, Berlin 1999, s. 466; H. Lilie [w:] B. Jähnke, H. Laufhütte, W. Odersky (red.), Strafgesetzbuch..., t. 16, s. 5. Zwolennikami tej koncepcji są m.in. J. Baumann, Körperverletzung oder Freiheitsdelikt, „Neue Juristische Wochenschrift” 1958, nr 51, s. 2093; A. Loose, Strafrechtliche..., s. 20-21, 38; R. Reniger, Strafrecht..., s. 104; G. Arzt, U. Weber, B. Heirich, E. Hilgendorf, Strafrecht..., s. 183-184; W. Bauer, Die strafrechtliche Beurteilung des ärztlichen Heileingriffs, Hamburg 2008, s. 89-142; V. Krey [w:] V. Krey, M. Heinrich, Strafrecht, besonderer Teil, t. 1, Stuttgart 2008, s. 99-100.

12 Zob. A. Loose, Strafrechtliche..., s. 20-21, 39 i nast.; H. Frister, M. Lindemann, T.A. Peters, Arztstrafrecht, München 2011, s. 1, 6; R. Reniger, Strafrecht..., s. 104; A. Eser, Rechtfertigungs und Entschuldigungsprobleme bei medizinischer Tätigkeit, [w:] A. Eser, G.P. Fletcher (red.), Rechtfertigungs und Entschuldigung Rechtsvergleichende Perspektiven, t. 2, Freiburg im Breisgau 1988, s. 1145; Bundesgerichtshof (dalej: BGH). Urteil vom 20. Januar 2004, 1 StR 319/03, pkt 4, www.bundesgerichtshof.de [dostęp: 22.05.2019 r.]; BGH. Urteil vom 23. Oktober 2007, 1 StR 238/07, https:/ / openjur.de/u/77576.html [dostęp: 22.05.2019 r.]. 
ponieważ poprawia, a nie pogarsza stan zdrowia pacjenta. Sąd Rzeszy zajął przeciwne stanowisko, przyjmując, że czyn lekarza wyczerpał ustawową istotę uszkodzenia ciała, ponieważ intencją ustawodawcy było objęcie tym zakazem „w najszerszym i ogólnym sensie każdego bezpośredniego i fizycznego naruszenia cielesnego organizmu" ${ }^{\prime 13}$. Później do stanowiska Sądu Rzeszy dołączył się Federalny Sąd Najwyższy (Bundesgerichtshof, BGH) w sprawie dotyczącej poszerzenia pola operacyjnego bez wcześniejszego uprzedzenia pacjentki i zapytania o zgodę na wypadek takiej konieczności. Uzasadniając możliwość zakwalifikowania zabiegu leczniczego bez zgody pacjenta jako uszkodzenie ciała, BGH wywiódł prawo do samostanowienia z prawa do nienaruszalności cielesnej (Recht auf körperliche Unversehrtheit), gwarantowanego w art. 2 ust. 2 zd. 1 Konstytucji RFN ${ }^{14}$, podkreślając, że wymaga ono uwzględnienia także u osoby, która nie godzi się na „poświęcenie swojej nienaruszalności cielesnej nawet dla uchylenia choroby zagrażającej życiu"15. W nowszym orzecznictwie BGH przeczytać można:

każdy lekarski środek leczniczy, ingerujący w integralność cielesną wyczerpuje obiektywną istotę umyślnego uszkodzenia ciała, niezależnie od tego, czy został zastosowany lege artis i czy jest skuteczny [...]. Potrzebuje dlatego szczególnego usprawiedliwienia, z reguły w skutecznej zgodzie pacjenta, zasadniczo udzielonej wyraźnie przed zastosowaniem leczenia ${ }^{16}$.

Elementarnym warunkiem skuteczności zgody jest poprzedzenie jej informacją "o interwencji, jej przebiegu, jej szansach powodzenia, ryzyku

13 Ostatecznie sąd pierwszej instancji rozpoznając sprawę ponownie, uniewinnił lekarza, przyjmując, że działał on w przekonaniu, że zabieg odpowiada woli rodziców dziecka, szerzej zob. C. Stooss, Chirurgische Operation und ärztliche Behandlung. Eine strafrechtliche Studie, Berlin 1898, s. 21-25, 108-126; W. Niese, Ein Beitrag zur Lehre vom ärztlichen Heileingriff, [w:] P. Bockelmann, W. Gallas (red.), Festschrift für Eberhard Schmidt zum 70. Geburtstag, Göttingen 1961, s. 364; B. Tag, Der Körperverletzungstatbestand..., s. 7-8.

14 Grundgesetz für die Bundesrepublik Deutschland in der im Bundesgesetzblatt Teil III, Gliederungsnummer 100-1, veröffentlichten bereinigten Fassung, das zuletzt durch Artikel 1 des Gesetzes vom 13. Juli 2017 (BGBl. I S. 2347) z późn. zm. (dalej: GG).

15 Zob. BGH, Urteil vom 28. November 1957, 4 StR 525/57, pkt 2 (tzw. Myom-Urteil), https:/ / opinioiuris.de/entscheidung/ 883 [dostęp: 22.05.2019 r.]; J. Baumann, Körperverletzung..., s. 2092-2093; O. Jürgens, Die Beschränkung der strafrechtlichen Haftung für ärztliche Behandlungsfehler, Frankfurt am Main 2005, s. 32; A. Loose, Strafrechtliche..., s. 21.

16 BGH. Urteil vom 22. Dezember 2010, 3 StR 239/10, pkt 9, www.bundesgerichtshof. de [dostęp: 22.05 .2019 r.]; podobnie BGH. Urteil vom 23. Oktober 2007, 1 StR 238/07, pkt II.2.a; BGH. Urteil vom 20. Januar 2004, 1 StR 319/03, pkt 4. 
i możliwych alternatywnych metodach leczenia" ${ }^{17}$. W konsekwencji § 223 StGB jest stosowany nawet wtedy, gdy zabieg leczniczy był udany, ale nie został należycie dopełniony obowiązek informacyjny ${ }^{18}$. Zgoda pacjenta występuje tu $\mathrm{w}$ funkcji okoliczności wyłączającej bezprawność (Rechtfertigungsgrund) ${ }^{19}$. Odnosi się do niej § 228 StGB, zgodnie z którym: „Kto dopuszcza się uszkodzenia ciała za zgodą osoby pokrzywdzonej, tylko wówczas działa bezprawnie, gdy czyn mimo zgody sprzeciwia się dobrym obyczajom (die guten Sitten verstößt)" ${ }^{20}$. Klauzula „dobrych obyczajów" pozwala na uwzględnienie w ocenie legalności interwencji leczniczej jej celu i zachowania zasad sztuki lekarskiej ${ }^{21}$. Błąd lekarza dotyczący udzielenia zgody lub jej skuteczności jest oceniany na płaszczyźnie

17 BGH. Urteil vom 23. Oktober 2007, 1 StR 238/07, pkt II.2.a; zob. też: BGH. Urteil vom 20. Januar 2004, 1 StR 319/03, pkt 4.

18 Zob. H. Lilie [w:] B. Jähnke, H. Laufhütte, W. Odersky (red.), Strafgesetzbuch..., t. 16, s. 6; N. Hengstenberg, Die hypothetische Einwilligung im Strafrecht, Berlin-Heidelberg 2013, s. 72-73; S. Seiterle, Hipotetyczna zgoda pacjenta na zabieg medyczny w niemieckim prawie karnym - skuteczny środek ograniczenia odpowiedzialności karnej, [w:] E. Hryniewicz, M. Małolepszy (red.), Karne aspekty spowodowania uszczerbku na zdrowiu w prawie niemieckim, polskim i austriackim, Poznań 2013, s. 116. Krytyczne uwagi P. Bockelmanna, zob. tenże, Strafrecht..., s. 63. W praktyce na wyłączenie odpowiedzialności karnej z § 223 StGB w przypadku niektórych uchybień w zakresie obowiązku informacyjnego pozwala wypracowana w orzecznictwie i doktrynie konstrukcja zgody hipotetycznej. Zakłada ona, że brak wymaganej informacji nie pozbawia zgody skuteczności, jeśli uchybienie to nie wpłynęło na decyzję pacjenta, czyli jeśli pacjent także przy prawidłowo udzielonej informacji zgodziłby się na daną interwencję, zob. BGH. Beschluss vom 15. Oktober 2003, 1 StR 300/03, pkt 3, https:/ / www.hrr-strafrecht.de/hrr/1/03/1-300-03.php3 [dostęp: 22.05.2019 r.]; BGH. Urteil vom 5. Juli 2007, 4 StR 549/06, pkt 16, https://www.hrr-strafrecht.de/hrr/4/06/4-549-06.php [dostęp: 22.05.2019 r.]; N. Hengstenberg, Die hypothetische..., s. 80-373; S. Seiterle, Hipotetyczna zgoda..., s. 119-124; R. Reniger, Strafrecht..., s. 106; T. Fischer, Strafgesetzbuch..., s. 1548; H. Frister, M. Lindemann, T.A. Peters, Arztstrafrecht, s. 18-19; C. Roxin, Strafrecht. Allegmeiner Teil, t. 1. Grundlagen. Der Aufbau der Verbrechenslehre, München 2006, s. 590-591; K. Kühl, M. Heger, Strafgesetzbuch..., s. 1120.

19 Zgodę występującą w tej funkcji tradycyjnie określa się terminem Einwilligung w odróżnieniu od Einverständnis wyłączającej ustawową istotę czynu, ale obecnie terminy te nie zawsze są stosowane konsekwentnie, zob. C. Roxin, Strafrecht..., t. 1, s. 540-545.

$20 \S 228$ StGB : „Wer eine Körperverletzung mit Einwilligung der verletzten Person vornimmt, handelt nur dann rechtswidrig, wenn die Tat trotz der Einwilligung gegen die guten Sitten verstößt".

21 Zob. BGH. Urteil vom 23. Oktober 2007, 1 StR 238/07, pkt II.2.a.; H.-J. Hirsch [w:] B. Jähnke, H. Laufhütte, W. Odersky (red.), Strafgesetzbuch ..., t. 16, s. 165; H. Frister, M. Lindemann, T.A. Peters, Arztstrafrecht, s. 6. 
błędu co do faktu, określonego przez ustawodawcę jako błąd co do okoliczności czynu (§ 16 StGB Irrtum über Tatumstände), jako że prawo niemieckie nie wyodrębnia błędu co do okoliczności wyłączającej bezprawność. Konsekwencją jest wyłączenie odpowiedzialności za przestępstwo umyślne z możliwością zakwalifikowania czynu jako przestępstwo nieumyślne (np. § 229 StGB) 22 .

W doktrynie na uzasadnienie koncepcji Rechtfertigungslösung powoływane są dwie zasadnicze racje. Pierwsza z nich, określana jako koncepcja "pojedynczego aktu” (Einzelaktstheorie), wymaga uwzględnienia przy ocenie interwencji leczniczej tego, że na początkowym etapie powoduje ona, zwłaszcza w przy padku zabiegu operacyjnego, uszkodzenie ciała i to zazwyczaj za wiedzą i wolą lekarza. Dokonywanie oceny na podstawie "salda" wynikającego z porównania początkowego i końcowego stanu pacjenta oznaczałoby stworzenie specjalnego uprawnienia dla lekarza ${ }^{23}$. Po drugie, zwolennicy omawianej koncepcji podnoszą, że ochrona z § 223 StGB nie może być ograniczana do integralności cielesnej rozumianej obiektywnie. Obejmuje ona także subiektywną wolność dysponowania własnym ciałem i zdrowiem ${ }^{24}$. Podobnie jak w sprawie Myom-Urteil, uzasadnienie to nawiązuje do ścisłego związku konstytucyjnego prawa do integralności cielesnej (art. 2 ust. 2 zd. 1 GG) z prawem do samostanowienia ${ }^{25}$.

22 Zob. K. Oswald, Heilversuch, Humanexperiment und Arzneimittelforschung. Eine systematische Einordnung humanmedizinischer Verschuchsbehandlung aus strafrechtlicher Sicht, [w:] C. Roxin, U. Schroth (red.), Handbuch des Medizinstrafrechts, Stuttgart i in. 2010, s. 694; BGH. Urteil vom 11. Oktober 2011, 1 StR 134/11, https://www.hrr-strafrecht.de/hrr/1/11/1134-11.php [dostęp: 22.05.2019 r.]; BGH. Urteil vom 5. Juli 2007, 4 StR 549/06, pkt 20; BGH. Urteil vom 20. Januar 2004, 1 StR 319/03, pkt 2c i 3.

${ }^{23}$ Zob. A. Loose, Strafrechtliche..., s. 24, 27; G. Arzt, U. Weber, B. Heirich, E. Hilgendorf, Strafrecht..., s. 184; V. Krey [w:] V. Krey, M. Heinrich, Strafrecht..., t. 1, s. 100.

24 Zob. J. Baumann, Körperverletzung..., s. 2093; A. Loose, Strafrechtliche..., s. 26; R.H.W. Hägele, Arzneimittelprüfung. Ein strafrechtlicher Vergleich aus deutscher, österreichischer, schweizerischer und internationalen Sicht, Baden-Baden 2004, s. 108, 109; W. Bauer, Die strafrechtliche..., s. 124-141.

25 Zob. J. Baumann, Körperverletzung..., s. 2093; A. Loose, Strafrechtliche..., s. 24-25; V. Krey [w:] V. Krey, M. Heinrich, Strafrecht..., t. 1, s. 100; A.-D. Jordan, Zur strafrechtlichen Zulässigkeit placebokontrollierter Terapiestudien, Frankfurt am Main 1988, s. 12; G. Arzt, U. Weber, B. Heirich, E. Hilgendorf, Strafrecht..., s. 183-184; W. Bauer, Die strafrechtliche..., s. $131-140$. 


\section{Tatbestandslösung}

Pogląd, że zabieg leczniczy wyczerpuje istotę czynu z § 223 StGB, spotkał się z krytyką ze strony części niemieckiej doktryny, w ramach koncepcji zwanej Tatbestandslösung ${ }^{26}$. Przyjmuje ona - z pewnymi różnicami w kwestiach szczegółowych - że interwencja lecznicza, wynikająca ze wskazań medycznych i przeprowadzona lege artis nie wyczerpuje istoty czynu zabronionego z § 223 StGB $^{27}$. Zdaniem zwolenników Tatbestandslösung, w powszechnej świadomości prawnej interwencja lecznicza nie przedstawia się jako uszkodzenie ciała - ani pojęciowo, ani pod względem swojej wartości - a zarazem ma na celu ochronę integralności cielesnej, życia i zdrowia ${ }^{28}$, toteż nie może być oceniana tak samo, jak „ugodzenie nożem przez «zabijakę»" ${ }^{29}$. Uznanie leczenia za uszkodzenie ciała jest dla lekarza stygmatyzujące ${ }^{30}$. Czynno-

26 Często wyrażany jest pogląd, że koncepcja Tatbestandslösung przeważa w doktrynie niemieckiej, zob. B. Tag, Der Körperverletzungstatbestand..., s. 29; K. Oswald, Heilversuch..., s. 687; W. Bauer, Die strafrechtliche..., s. 13; K. Ulsenheimer [w:] K. Ulsenheimer, E. Biermann, R.W. Bock, Arztstrafrecht..., s. 190; G. Arzt, U. Weber, B. Heirich, E. Hilgendorf, Strafrecht..., s. 183-184. Dostrzega się jednak rosnące znaczenie Rechtfertigungslösung, zob. H. Lilie [w:] B. Jähnke, H. Laufhütte, W. Odersky (red.), Strafgesetzbuch..., t. 16, s. 5; R. Maurach, F.C. Schroeder, M. Maiwald, Strafrecht. Besonderer Teil, t. 1, Heidelberg 2009, s. 113. Zdaniem A. Esera spór nie doczekał się jednolitego rozstrzygnięcia, zob. tenże, Zur Regelung..., s. 472.

27 Zob. A. Eser, Rechtfertigungs und Entschuldigungsprobleme..., s. 1145. Zwolennikami tej koncepcji są m.in. C. Stooss, Chirurgische..., s. 2-12; H. Lilie [w:] B. Jähnke, H. Laufhütte, W. Odersky (red.), Strafgesetzbuch..., t. 16, s. 5; H.-J. Hirsch [w:] B. Jähnke, H. Laufhütte, W. Odersky (red.), Strafgesetzbuch..., t. 16, s. 151; P. Bockelmann, Strafrecht..., s. 62-68; G. Grünwald, Heilbehandlung und Ärztliche Aufklärungspflicht, [w:] H. Göppingen (red.), Arzt und Recht, medizinisch-juristiche Grenzprobleme unserer Zeit, München 1966, s. 136-139; W. Niese, Ein Beitrag..., s. 364, 367; K. Engisch, Ärztlicher Eingriff zu Heilzwecken und Einwilligung, „Zeitschrift für die gesamte Strafrechtswissenschaft” 1939, nr 1, s. 5-8; K.H. Gössel, D. Dölling, Strafrecht. Besonderer Teil, t. 1. Straftaten gegen Persönlichkeits- und Gemeinschaftswerte, Heidelberg 2004, s. 154; R. Maurach, F.C. Schroeder, M. Maiwald, Strafrecht..., t. 1, s. 113; K. Kühl, M. Heger, Strafgesetzbuch..., s. 1086; P. Held, Strafrechtliche Beurteilung von Humanexperimenten und Heilversuchen in der medizinischen Diagnostik, Berlin 1990, s. 32-33; A. Kaufmann, Die eigenmächtige Heilbehandlung, "Zeitschrift für die gesamte Strafrechtswissenschaft" 1961, nr 3, s. 372-373; H. Welzel, Das Deutsche Strafrecht. Eine systematische Darstellung, Berlin 1969 [przedruk: Berlin 1989], s. 289.

28 Zob. H. Welzel, Das Deutsche..., s. 289; G. Grünwald, Heilbehandlung..., s. 136-137.

29 P. Bockelmann, Strafrecht..., s. 62.

30 Zob. tamże; A. Eser, Medizin und Strafrecht. Eine schutzgutorientierte Problemübersicht, "Zeitschrift für die gesamte Strafrechtswissenschaft" 1985, nr 1, s. 19. 
ści medyczne, które przywracają, poprawiają lub zachowują zdrowie, nie naruszają dobra prawnego. Wyeliminowanie cielesnego defektu lub zapobiegnięcie mu stanowi przeciwieństwo uszkodzenia ciała. Przy ocenie tej należy uwzględnić nie pojedyncze, cząstkowe czynności (przecięcie, ukłucie, usunięcie chorego organu), będące środkiem do celu, jakim jest wyleczenie, ale całość czynu razem z wynikającym z niego ostatecznym rezultatem, ustalając, czy był to zamach na zdrowie jako na całość dobra prawnego ${ }^{31}$. Można tu spotkać porównanie do naprawy przedmiotu, której nie uznaje się za realizację ustawowej istoty uszkodzenia rzeczy nawet, jeśli wymaga, aby najpierw rzecz rozebrać na części i czasowo pozbawić właściwych jej funkcji ${ }^{32}$. Ponadto, w ocenie większości zwolenników Tatbestandslösung, dobro chronione zakazem uszkodzenia ciała nie obejmuje prawa do samostanowienia, ponieważ $\mathrm{w}$ przeciwnym razie ochronie podlegałoby nie tyle ciało, ale dopiero wola ochrony jego nienaruszalności, a to zatarłoby różnicę między uszkodzeniem ciała a przestępstwami przeciwko wolności ${ }^{33}$.

Rozbieżności w ramach koncepcji Tatbestandslösung pojawiają się w kwestii, czy jest to ocena niezależna od skutku zabiegu, tj. czy dotyczy też zabiegu nieudanego ${ }^{34}$. Na tym tle doszło do wykształcenia się teorii skutku i teorii działania. Pierwsza z nich różnicuje zabieg leczniczy udany i nieudany, przyjmując, że jeśli zabieg jako całość pogorszył stan zdrowia pacjenta, to doszło do naruszenia $\S 223 \mathrm{StGB}^{35}$. Druga natomiast uznaje, że zabieg uzasadniony wskazaniami lekarskimi i przeprowadzony lege artis nie wyczerpuje ustawowej istoty uszkodzenia ciała, niezależnie od swojego skutku' ${ }^{36}$. Obok tego, niektórzy zwolennicy Tatbestandslösung

31 Zob. C. Stooss, Chirurgische..., s. 8-9, 13; P. Bockelmann, Strafrecht..., s. 66-67; H. Lilie [w:] B. Jähnke, H. Laufhütte, W. Odersky (red.), Strafgesetzbuch..., t. 16, s. 4, 9; K.H. Gössel, D. Dölling, Strafrecht..., t. 1, s. 154; R. Maurach, F.C. Schroeder, M. Maiwald, Strafrecht..., t. 1, s. 113; K. Engisch, Arztlicher..., s. 5.

32 Zob. P. Bockelmann, Strafrecht..., s. 66-67.

33 Zob. H. Lilie [w:] B. Jähnke, H. Laufhütte, W. Odersky (red.), Strafgesetzbuch..., t. 16, s. 5; G. Grünwald, Heilbehandlung..., s. 138; P. Held, Strafrechtliche..., s. 32-33.

34 Zob. B. Tag, Der Körperverletzungstatbestand..., s. 22-28.

35 Zob. C. Stooss, Operativer Eingriff und Körprerverletzung, "Zeitschrift für Schweizer Strafrecht" 1893, t. 6, s. 53-61 [przedruk w: A. Eser, A. Künschner (red.), Recht und Medizin, Darmstadt 1990, s. 56, 63-64]; P. Bockelmann, Strafrecht..., s. 67-69; A. Kaufmann, Die eigenmächtige..., s. 373; K.H. Gössel, D. Dölling, Strafrecht..., t. 1, s. 155-156.

36 Zob. H. Welzel, Das Deutsche..., s. 289; G. Grünwald, Heilbehandlung ..., s. 138-139, 128-129; K. Engisch, Ärztlicher..., s. 9; P. Held, Strafrechtliche..., s. 33; H. Lilie [w:] B. Jähnke, H. Laufhütte, W. Odersky (red.), Strafgesetzbuch..., t. 16, s. 12-13. 
interpretują przedmiot ochrony § 223 StGB w sposób zbliżony do Rechtfertigungslösung. Warta uwagi jest tutaj koncepcja A. Esera, który uznaje, że istoty uszkodzenia ciała nie wyczerpują tylko interwencje służące zachowaniu lub poprawie zdrowia bez istotnej zmiany substancji ciała. Legalność interwencji leczniczych przekraczających ten stopień dotkliwości (naruszających substancję ciała lub pogarszających stan zdrowia) autor uzależnia od zgody pacjenta, której udzielenie wyłącza ustawową istotę czynu z § 223 StGB $^{37}$. Zdaniem A. Esera, powyższy zakaz karny chroni prawo do samostanowienia, ale nie samo w sobie, lecz w powiązaniu $\mathrm{z}$ nienaruszalnością cielesną, czyli w zakresie ochrony człowieka przed znoszeniem, wbrew swojej woli, uszczerbku na zdrowiu lub w konstytucji cielesnej38. Jeszcze dalej idzie B. Tag, która podobnie jak A. Eser uznaje, że § 223 StGB obejmuje ochroną - obok „biologicznego stanu ciała i jego funkcji” - także związane z nimi prawo do samostanowienia. Wywodzi stąd jednak wniosek, że brak zgody pacjenta powoduje wyczerpanie ustawowej istoty przestępstwa z $\$ 223$ StGB niezależnie od tego, czy interwencja lecznicza narusza substancję ciała lub pogarsza stan zdrowia ${ }^{39}$.

\section{W poszukiwaniu podstaw ochrony karnej prawa pacjenta do samostanowienia}

Tytułowy spór jest w dużej mierze uwarunkowany brakiem w prawie niemieckim odrębnej kryminalizacji interwencji leczniczej przeprowadzonej bez zgody pacjenta ${ }^{40}$. Mimo postulatów części doktryny ${ }^{41} \mathrm{i}$ ponawianych

37 Zob. A. Eser, Zur Regelung..., s. 467; tenże [w:] A. Schönke, H. Schröder, Strafgesetzbuch. Kommentar, München 1991, s. 1635-1638; tenże, Medizin..., s. 17-19; zob. też A. Liszewska, Odpowiedzialność karna..., s. 81-83.

38 Zob. A. Eser, Medizin..., s. 18-19.

39 Zob. B. Tag, Der Körperverletzungstatbestand..., s. 441. Podobnie zob. U. Schroth, Ärztliches Handeln und strafrechtlicher Maßstab. Medizinische Eingriffe ohne und mit Einwilligung, ohne und mit Indikation, [w:] C. Roxin, U. Schroth (red.), Handbuch des Medizinstrafrechts, Stuttgart i in. 2010, s. 27-28, 31-32, a w zakresie zabiegu nieudanego, zob. K.H. Gössel, D. Dölling, Strafrecht..., t. 1, s. 155-156.

40 Zob. R. Reniger, Strafrecht..., s. 104-105.

41 Zob. O. Jürgens, Die Beschränkung..., s. 34-35; G. Schwalm, Zu einigen ungelösten Strafrechtsproblemen, [w:] P. Bockelmann (red.), Festschrift für Karl Engisch zum 70. Geburtstag, 
inicjatyw legislacyjnych ${ }^{42}$ ustawodawca nie zdecydował się na wprowadzenie takiego typu przestępstwa, w odróżnieniu od prawa austriackiego ${ }^{43}$ czy choćby polskiego art. 192 k.k. Dlatego szeroka aprobata dla Rechtfertigungslösung, zwłaszcza obecna w orzecznictwie, tłumaczona jest tym, że wskazana koncepcja otwiera możliwość przyjęcia § 223 StGB za podstawę ochrony prawa pacjenta do samostanowienia ${ }^{44}$. Upatruje się $\mathrm{w}$ niej nawet przejaw wykładni prokonstytucyjnej powołanego przepisu karnego ${ }^{45}$. W kontekście tego problemu należy jednak zwrócić uwagę na dwie kwestie.

Po pierwsze, konstytucyjny rodowód prawa pacjenta do samostanowienia wywodzi się $\mathrm{w}$ prawie niemieckim $\mathrm{z}$ nienaruszalności cielesnej. Trudno odmówić racji stanowisku, że tak określone dobro prawne nie obejmuje wyłącznie zdrowia, ale także pewien obszar wolności człowieka związany z decydowaniem, czy dla zachowania zdrowia poddać się obciążeniom i dolegliwościom związanym nieuchronnie z interwencją leczniczą ${ }^{46}$. Na gruncie ponadnarodowym funkcjonuje kategoria integralności fizycznej

Frankfurt am Main 1969, s. 550; A. Eser [w:] A. Schönke, H. Schröder, Strafgesetzbuch..., s. 1634.

42 Ostatnio był to projekt Ministerstwa Sprawiedliwości z 1996 r., który przewidywał w § 229 ust. 1 kryminalizację "samowolnego postępowania leczniczego" (eigenmächtige Heilbehandlung) opisanego jako podjęcie u innej osoby, bez skutecznej zgody, interwencji cielesnej (körperliche Eingriff) lub innego postępowania oddziałującego na integralność cielesną lub zdrowie w stopniu wyższym niż nieznaczny, w celu rozpoznania, leczenia, złagodzenia lub zapobieżenia obecnej lub przyszłej, fizycznej lub psychicznej chorobie, uszczerbkowi, cierpieniu, dolegliwości lub zaburzeniu u tej osoby lub jej płodu, zob. H. Lilie [w:] B. Jähnke, H. Laufhütte, W. Odersky (red.), Strafgesetzbuch..., t. 16, s. 13-14; O. Jürgens, Die Beschränkung..., s. 13-14, 35. O wcześniejszych projektach, zob. P. Bockelmann, Strafrecht..., s. 63; G. Grünwald, Heilbehandlung..., s. 152-158.

43 Bundesgesetz vom 23. Jänner 1974 über die mit gerichtlicher Strafe bedrohten Handlungen (Strafgesetzbuch - StGB), „Bundesgesetzblatt für die Republik Österreich” nr 60/1974, z późn. zm., https://www.ris.bka.gv.at, [dostęp: 22.05 .2019 r.], § 110 ust. 1 o treści: „Kto leczy inną osobę bez jej zgody, nawet jeśli zachowuje reguły wiedzy medycznej, podlega karze pozbawienia wolności do 6 miesięcy lub grzywny do 360 stawek dziennych"; R.H.W. Hägele, Arzneimittelprüfung..., s. 110 i nast.; A. Eser, Zur Regelung..., s. 471.

${ }_{44}$ Zob. O. Jürgens, Die Beschränkung..., s. 32-33; H. Lilie [w:] B. Jähnke, H. Laufhütte, W. Odersky (red.), Strafgesetzbuch..., t. 16, s. 13; A. Eser, Medizin ..., s. 17-19; G. Schwalm, Zu einigen..., s. 550; A. Eser [w:] A. Schönke, H. Schröder, Strafgesetzbuch..., s. 1634; G. Grünwald, Heilbehandlung..., s. 139; A. Loose, Strafrechtliche..., s. 43; N. Hengstenberg, Die hypothetische..., s. 69-70; W. Niese, Ein Beitrag..., s. 365; R. Reniger, Strafrecht..., s. 104-105.

45 Zob. W. Bauer, Die strafrechtliche..., s. 115-117, 142.

${ }^{46}$ Zob. B. Tag, Der Körperverletzungstatbestand..., s. 76-77, 81. 
i psychicznej o podobnie kompleksowej treści, lokowana w obszarze prawa do życia prywatnego z art. 8 Europejskiej Konwencji Praw Człowieka ${ }^{47}$ oraz będąca podstawą wymogu poszanowania wolnej i świadomej w kontekście biomedycznym, w świetle art. 3 ust. 2 Karty Praw Podstawowych $\mathrm{UE}^{48}$. Nienaruszalność cielesna jest również dobrem rodzajowym wskazanym w tytule rozdziału 17. StGB, w którym zamieszczono powoływany $\S 223$ (Straftaten gegen die körperliche Unversehrtheit). Zarazem, nawet literalnie interpretowany, zakres tego zakazu karnego wykracza poza ochronę zdrowia, ponieważ obejmuje też fragment obszaru dobra prawnego określanego na gruncie prawa polskiego jako nietykalność cielesna ${ }^{49}$.

Po drugie, poszukiwanie w $\S 223$ StGB ochrony prawa pacjenta do samostanowienia dostrzegalne jest także i u zwolenników Tatbestandslösung. Różnica sprowadza się do tego, że zgoda konieczna do uznania interwencji leczniczej za legalną uznawana jest wówczas za okoliczność wyłączającą ustawową istotę czynu, a nie okoliczność wyłączającą bezprawność. Rechtfertigungslösung nie jest zatem jedyną możliwością ochrony prawa pacjenta do samostanowienia w systemie prawa, który nie kryminalizuje odrębnie przeprowadzenia interwencji leczniczej bez zgody pacjenta.

Skoro koncepcja Tatbestandslösung pozwala na włączenie zgody do ustawowej istoty przestępstwa z § 223 StGB, nasuwa się wniosek, że tytułowy spór nie jest uwarunkowany wyłącznie kwestią ochrony prawa pacjenta do samostanowienia. Przenosząc to na grunt polski, należałoby stwierdzić, że odrębna kryminalizacja zabiegu leczniczego bez zgody pacjenta nie przesądza de lege lata o rozstrzygnięciu lub dezaktualizacji omawianego sporu. Podnoszone $w$ nim racje nie są immanentnie związane z kwestią zgody na zabieg leczniczy. Zarazem - wbrew twierdzeniom

47 Zob. wyrok Europejskiego Trybunału Praw Człowieka z dnia 26 marca 1985 r. w sprawie X. i Y. przeciwko Holandii, skarga nr 8978/80, § 22, https://hudoc.echr.coe.int/ [dostęp: 22.05 .2019 r.]; wyrok Europejskiego Trybunału Praw Człowieka z dnia 22 października 1996 r., w sprawie Stubbings i in. przeciwko Zjednoczonemu Królestwu, skarga nr 22083/93, 22095/93, § 61, https:/ / hudoc.echr.coe.int/ [dostęp: 22.05 .2019 r.]; A. Wnukiewicz-Kozłowska, Eksperyment medyczny na organizmie ludzkim w prawie międzynarodowym i europejskim, Warszawa 2004, s. 87; M. Safjan, Prawo do ochrony życia prywatnego, [w:] L. Wiśniewski (red.), Podstawowe prawa jednostki i ich sądowa ochrona, Warszawa 1997, s. 127.

48 Zob. A. Wnukiewicz-Kozłowska, Eksperyment..., s. 65, 88-89.

49 Zob. A. Eser, Medizin..., s. 5; G. Hochmayr, Karalne uszkodzenie ciała w Niemczech i Austrii. Zaskakujące rozbieżności, [w:] E. Hryniewicz, M. Małolepszy (red.), Karne aspekty spowodowania uszczerbku na zdrowiu w prawie niemieckim, polskim i austriackim, Poznań 2013, s. 25-26. 
zwolenników pierwotnej legalności zabiegu leczniczego ${ }^{50}$ - uznanie takiej interwencji za kontratyp nie oznacza konieczności kwalifikowania zabiegu leczniczego przeprowadzonego lege artis, ale bez zgody pacjenta, z przepisów chroniących zdrowie. Wskazany zarzut opiera się na założeniu, że w koncepcji wtórnej legalności zabiegu leczniczego zgoda pacjenta należy do znamion kontratypu. Tymczasem kontratyp zabiegu leczniczego nie musi obejmować zgody pacjenta ${ }^{51}$, a nawet jeśli przyjąć, że obejmu$\mathrm{je}^{52}$, to niespełnienie tylko tej przesłanki oznacza, że zabieg nie znajduje usprawiedliwienia wyłącznie $\mathrm{w}$ zakresie zamachu na prawo pacjenta do samostanowienia, a nie $\mathrm{w}$ zakresie zamachu na zdrowi $^{53}$.

\section{Uniwersalny wymiar dyskusji nad podstawą legalności zabiegu leczniczego}

Poza specyfikę niemieckiego stanu prawnego wykracza z pewnością teza zwolenników Tatbestandslösung, że uznanie zabiegu leczniczego za uszkodzenie ciała jest stygmatyzujące dla lekarza, powoływana także w doktrynie polskiej, która wskazuje na doniosłość funkcji lekarza i wyraża obawy podważenia jej w razie „dopiero" wtórnego wyłączenia bezprawności ${ }^{54}$. Twierdzenie to spotkało się jednak w doktrynie niemieckiej z krytyczną reakcją nie tylko zwolenników Rechtfertigungslösung, ale nawet

50 Zob. W. Wróbel, A. Zoll, Polskie prawo karne..., s. 168.

51 Zob. P. Daniluk, Czynność lecznicza..., s. 32, 36-38; M. Cieślak, Polskie prawo karne..., s. 243-244.

52 Zob. R.A. Stefański, Prawo karne materialne. Część ogólna, Warszawa 2008, s. 153; M. Mozgawa [w:] M. Mozgawa (red.), Prawo karne materialne..., s. 299-300; I. Zgoliński [w:] I. Zgoliński, I. Zduński, Okoliczności wyłączające bezprawność..., s. 70; W. Wolter, Nauka o przestępstwie, s. 197-198; J. Piórkowska-Flieger, M. Szwarczyk, Warunki dopuszczalności zabiegu..., s. 147-148; A. Marek, Prawo karne, s. 182.

53 Zob. J. Śliwowski, Prawo karne, s. 156-157; J. Warylewski, Prawo karne..., s. 285; M. Mozgawa [w:] M. Mozgawa (red.), Prawo karne materialne..., s. 300; I. Zgoliński [w:] I. Zgoliński, I. Zduński, Okoliczności wyłaczające bezprawność..., s. 71, 72; J. Piórkowska-Flieger, M. Szwarczyk, Warunki dopuszczalności zabiegu..., s. 154. Zob. też M. Filar, Leczenie - sztuka..., s. 62; M. Filar, Rec.: A. Zoll, „Odpowiedzialność karna lekarza za niepowodzenie w leczeniu”, Warszawa 1988, „Państwo i Prawo” 1990, z. 1, s. 121; A. Marek, Prawo karne, s. 182.

54 R. Kędziora określa nawet legalność pierwotną czynu jako „przywilej” w stosunku do legalności wtórnej, zob. taż, Odpowiedzialność karna lekarza..., s. 49, 285. 
i Tatbestandslösung. Podnosi się, że dla negatywnej oceny uszkodzenia ciała nie wystarcza sam zakaz z § 223 StGB, lecz konieczny jest nadto brak podstaw do wyłączenia bezprawności ${ }^{55}$. Tytułem przykładu przedstawiane jest zatrzymanie osoby podejrzanej przez policjanta lub orzeczenie kary pozbawienia wolności przez sędziego, które należy uznać za czyn wyczerpujący ustawową istotę pozbawienia wolności, usprawiedliwiony - na płaszczyźnie oceny bezprawności - uprawnieniami służbowymi ${ }^{56}$. Kontynuując tę krytykę, wskazanym obawom o prestiż zawodu lekarza należałoby też przeciwstawić doniosłość praw pacjenta, który niemal zawsze jest słabszą w stosunku do lekarza stroną relacji prawnomedycznych, a w przypadku zabiegu leczniczego znajduje się w sytuacji z natury rzeczy przymusowej, jaką tworzy stan chorobowy ${ }^{57}$. Uznając, że zabieg leczniczy nie wyczerpuje znamion przestępstwa przeciwko zdrowiu, zakłada się, że proces leczenia nie stwarza dla pacjenta żadnych, choćby ubocznych, dolegliwości, podobnie jak dla właściciela demontaż urządzenia technicznego w celu naprawy. Wchodząc w spór, która droga wyłączenia bezprawności czynu - pierwotna czy wtórna - jest „lepsza”, można by wręcz dowodzić, że wtórna legalność zabiegu leczniczego nie tylko lekarzowi nie uwłacza, ale jest przejawem zaufania społecznego wobec wykonywanego przezeń zawodu, skoro powierza mu się witalne dobra prawne aż do granic zalegalizowania czynu naruszającego zakaz ingerencji w te dobra ${ }^{58}$. Jak słusznie jednak stwierdzają niemieccy autorzy, chodzi tutaj nie o prestiż lekarza, ale o rozstrzygnięcie problemu prawnokarnego, czy skutki interwencji leczniczej, czyli ingerencję w nienaruszalność cielesną związaną z leczeniem i szanse na poprawę zdrowia, jaką ona daje, należy rozliczać per saldo ${ }^{59}$.

Z tej perspektywy zwolennicy Rechtfertigungslösung wskazują na doniosłą rację przemawiającą przeciwko tezie, że zabieg leczniczy, choćby

55 Zob. A. Loose, Strafrechtliche..., s. 27-28, 30; G. Grünwald, Heilbehandlung..., s. 135.

56 Zob. A. Loose, Strafrechtliche..., s. 28; H. Frister, M. Lindemann, T.A. Peters, Arztstrafrecht, s. 2; H. Lilie [w:] B. Jähnke, H. Laufhütte, W. Odersky (red.), Strafgesetzbuch..., t. 16, s. 12.

57 Zob. P. Daniluk, Czynność lecznicza..., s. 31.

58 Jak zauważa B. Tag, zwolenniczka Tatbestandslösung, to właśnie odrębny zakaz karny mający za przedmiot interwencję leczniczą (np. bez zgody pacjenta) mógłby być odczytywany jako przejaw "szczególnego prawa karnego dla lekarzy”, uznawanego za przejaw bądź to ich uprzywilejowania, bądź to stygmatyzacji, zob. B. Tag, Der Körperverletzungstatbestand..., s. 455.

59 Zob. H. Frister, M. Lindemann, T.A. Peters, Arztstrafrecht, s. 2. 
i przeprowadzony lege artis, nie stanowi zamachu na dobra prawne. W jego istotę zazwyczaj wpisane jest naruszenie integralności cielesnej pacjenta. Przecięcie ciała przez chirurga lub podanie środka znieczulającego przez anestezjologa - jakiemukolwiek celowi by nie służyły - nie są działaniami obojętnymi dla ludzkiego organizmu, zarówno same w sobie, jak i ze względu na ich nieuchronne następstwa (rana i ból pooperacyjny czy dolegliwości po znieczuleniu ogólnym). Stanowią przejaw poświęcenia pewnego obszaru zdrowia w celu ratowania tego dobra w innym aspekcie, zazwyczaj istotniejszym dla całokształtu funkcjonowania człowieka, lub w celu ratowania życia. To dwukierunkowe oddziaływanie zabiegu leczniczego łączy się z faktem, że zdrowie ma cechę stopniowalności, a zarazem dotyczy wielu aspektów funkcjonowania człowieka. Aspekty te są jednak wzajemnie uwarunkowane i zazwyczaj niemożliwe do rozdzielenia. Organizmu biologicznego nie da się - jak chciał P. Bockelmann - porównać do maszyny, którą mechanik wyłączy, rozłoży na części, naprawi, złoży i uruchomi ponownie. Proces „naprawy” jest zazwyczaj dla niego obciążający sam w sobie. Co więcej, nie zawsze skutki tego procesu mają charakter przejściowy, jak wspomniany ból pooperacyjny. Właściwe dla zabiegu leczniczego naruszenie integralności cielesnej pozostawia niekiedy zmiany nieodwracalne, co ukazuje choćby przykład amputacji kończyny lub usunięcia organu.

Wbrew zarzutom ze strony zwolenników Tatbestandslösung ${ }^{60}$ przyjęcie wtórnej legalności zabiegu leczniczego nie skutkuje koniecznością kwalifikowania wszelkich spowodowanych nim uszczerbków na zdrowiu jako objętych umyślnością. W szczególności do odpowiedzialności za przestępstwo umyślne nie muszą prowadzić uchybienia zasadom postępowania lege artis ${ }^{61}$. Zarzut ten opiera się na całościowej ocenie zabiegu leczniczego („per saldo"), typowym dla założenia o jego legalności pierwotnej. Należałoby raczej przyjąć, że bezprawność umyślnego naruszenia integralności cielesnej pacjenta zostaje zniesiona na podstawie istnienia obiektywnych wskazań do jego przeprowadzenia oraz realizacji celu leczniczego ${ }^{62}$. Wpisana $\mathrm{w}$ lex artis zabiegu leczniczego umyślność naruszenia integralności

60 Zob. P. Bockelmann, Strafrecht..., s. 52; A. Zoll, Odpowiedzialność karna..., s. 9-10.

${ }^{61}$ W literaturze niemieckiej zob. A. Loose, Strafrechtliche..., s. 40.

${ }^{62}$ Oznaczałoby to, tytułem przykładu, że jeśli stan pacjenta wymaga operacji serca i w tym celu następuje otwarcie jego klatki piersiowej, umyślny uszczerbek na zdrowiu spowodowany tą czynnością nie ma cech bezprawności. Bezprawne, i ocenione jako nieumyślne, mogą być dalsze czynności w razie błędu w przeprowadzeniu operacji. 
cielesnej nie przesądza zaś tego, że również umyślnością lekarz obejmuje nieudany docelowy efekt zabiegu, $\mathrm{np}$. trwałe pogorszenie stanu zdrowia operowanego pacjenta w wyniku błędu w postępowaniu medycznym. Konsekwencje takiego błędu zazwyczaj objęte są nieumyślnością i dają podstawę do odpowiedzialności karnej za nieumyślne przestępstwa skutkowe. Przyjmując wtórną legalność zabiegu leczniczego, w kategoriach umyślności należałoby rozważyć dopiero przeprowadzenie go bez wskazań medycznych, co w pewnej mierze wymusza przyjęta w prawie polskim konstrukcja błędu co do kontratypu (art. 29 k.k.). Na gruncie prawa niemieckiego błąd co do istnienia wskazań do interwencji leczniczej podlega takiej samej ocenie, jak błąd co do okoliczności czynu (§16 StGB), który wyłącza odpowiedzialność za czyn umyślny.

\section{Podsumowanie}

Niemiecka dyskusja na temat podstaw legalności interwencji leczniczej jest niewątpliwie naznaczona problemem odpowiedzialności karnej za interwencję leczniczą bez zgody pacjenta. Z uwagi na brak odrębnej kryminalizacji takiego czynu, jego kwalifikacji poszukuje się $\mathrm{w}$ przepisach chroniących nienaruszalność cielesną, w szczególności w § 223 StGB, co wpisuje się w koncepcję Rechtfertigungslösung i służy niewątpliwie jej aprobacie, zwłaszcza w orzecznictwie. Podobny efekt w ochronie prawa pacjenta do samostanowienia można jednak osiągnąć także na gruncie założenia, że prawidłowo przeprowadzona interwencja lecznicza nie narusza ustawowej istoty czynu z $§ 223$ StGB (Tatbestandlösung), jeśli do kryteriów owej prawidłowości włączyć zgodę pacjenta. Problem odpowiedzialności karnej za interwencję leczniczą bez zgody pacjenta nie jest zatem jedynym elementem spornym w przedstawionej dyskusji, która nie traci na aktualności w systemie prawa wyodrębniającym ochronę prawa pacjenta do samostanowienia w ramach zakazu karnego o treści zbliżonej do polskiego art. 192 k.k. Drugą, a może nawet fundamentalną, kwestią sporną, którą wyraźnie ukazuje doktryna niemiecka, jest to, czy uwzględniać w ocenie prawnej uboczne i nieuniknione dolegliwości dla ludzkiego organizmu, nieuchronnie związane z interwencją leczniczą. Na tej płaszczyźnie konfrontacja między koncepcją Rechtfertigungslösung i Tatbestandlösung ma wymiar uniwersalny i zdaje się dostarczać mocnych racji tezie 
o wtórnej legalności zabiegu leczniczego. Już z tego powodu nie sposób zgodzić się ze spotykanym w literaturze polskiej stanowiskiem, że problem legalności zabiegu leczniczego został już rozstrzygnięty w kierunku legalności pierwotnej ${ }^{63}$. Można by co najwyżej podważać zasadność sporu z perspektywy konsekwencji praktycznych ${ }^{64}$. Jeśli jednak zakłada się rozróżnienie wtórnej i pierwotnej legalności czynu odpowiadającego prima facie treści zakazu karnego, to konieczność dokonania wyboru między tymi dwoma kierunkami uzasadnienia legalności zabiegu leczniczego jest nieunikniona.

Słowa kluczowe: prawo karne, prawo medyczne, zabieg leczniczy, legalność zabiegu leczniczego, wyłączenie bezprawności

\section{Bibliografia}

Arzt G., U. Weber, B. Heirich, E. Hilgendorf, Strafrecht. Besonderer Teil. Lerbuch, Bielefeld 2009.

Bauer W., Die strafrechtliche Beurteilung des ärztlichen Heileingriffs, Hamburg 2008.

Baumann J., Körperverletzung oder Freiheitsdelikt, „Neue Juristische Wochenschrift” 1958, nr 51, s. 2092-2094.

Bockelmann P., Strafrecht des Arztes, Stuttgart 1968.

Bojarski M., J. Giezek, Z. Sienkiewicz, Prawo karne materialne. Część ogólna i szczególna, M. Bojarski (red.), Warszawa 2015.

Buchała K., Prawo karne materialne, Warszawa 1989.

Cieślak M., Polskie prawo karne. Zarys systemowego ujęcia, Warszawa 1994.

Daniluk P., Czynność lecznicza jako kontratyp, „Prawo i Medycyna” 2008, nr 2, s. 2743.

Duda J., Transplantacja w prawie polskim. Aspekty karnoprawne, Kraków 2004.

Dukiet-Nagórska T., Autonomia pacjenta a polskie prawo karne, Warszawa 2008.

Engisch K., Ärztlicher Eingriff zu Heilzwecken und Einwilligung, "Zeitschrift für die gesamte Strafrechtswissenschaft" 1939, nr 1, s. 1-36.

${ }^{63}$ Zob. M. Filar, Odpowiedzialność karna..., s. 59-61; R. Kędziora, Odpowiedzialność karna lekarza..., s. 63.

${ }^{64} \mathrm{~W}$ polskim prawie sprowadzają się one do oceny błędu co do warunków legalności zabiegu leczniczego. W ramach legalności wtórnej podstawą tej oceny jest błąd co do kontratypu (art. 29 k.k.), a przy założeniu legalności pierwotnej - błąd co do ustawowych znamion ( 28 § 1 k.k.). 
Eser A., Medizin und Strafrecht. Eine schutzgutorientierte Problemübersicht, "Zeitschrift für die gesamte Strafrechtswissenschaft" 1985, nr 1, s. 1-46.

Eser A., Rechtfertigungs und Entschuldigungsprobleme bei medizinischer Tätigkeit, [w:] A. Eser, G.P. Fletcher (red.), Rechtfertigungs und Entschuldigung Rechtsvergleichende Perspektiven, t. 2, Freiburg im Breisgau 1988, s. 1443-1485.

Eser A., Zur Regelung der Heilbehandlung in rechtsvergleichender Perspektive, [w:] T. Weigend (red.), Festschrift für Hans Joachim Hirsch zum 70. Geburtstag am 11. April 1999, Berlin 1999, s. 465-483.

Filar M., Leczenie - sztuka czy rzemiosto? (nowe polskie lekarskie prawo karne), [w:] L. Tyszkiewicz (red.), Problemy nauk penalnych. Prace ofiarowane Pani Profesor Oktawii Górniok, Katowice 1996, s. 56-62.

Filar M., Lekarskie prawo karne, Kraków 2000.

Filar M., Odpowiedzialność karna związana z nieterapeutycznymi czynnościami lekarskimi, „Prawo i Medycyna” 2000, nr 5, s. 59-72.

Filar M., Rec.: A. Zoll, „Odpowiedzialność karna lekarza za niepowodzenie w leczeniu”, Warszawa 1988, „Państwo i Prawo” 1990, z. 1, s. 119-123.

Fischer T., Strafgesetzbuch mit Nebengesetzen, München 2014.

Frister H., M. Lindemann, T.A. Peters, Arztstrafrecht, München 2011.

Gardocki L., Prawo karne, Warszawa 2006.

Gössel K.H., D. Dölling, Strafrecht. Besonderer Teil, t. 1. Straftaten gegen Persönlichkeits- und Gemeinschaftswerte, Heidelberg 2004.

Grünwald G., Heilbehandlung und Ärztliche Aufklärungspflicht, [w:] H. Göppingen (red.), Arzt und Recht, medizinisch-juristiche Grenzprobleme unserer Zeit, München 1966, s. 125-158.

Grześkowiak A. [w:] A. Marek (red.), Prawo karne. Zagadnienia teorii i praktyki, Warszawa 1986, s. 134-135.

Hägele R.H.W., Arzneimittelprüfung. Ein strafrechtlicher Vergleich aus deutscher, österreichischer, schweizerischer und internationalen Sicht, Baden-Baden 2004.

Held P., Strafrechtliche Beurteilung von Humanexperimenten und Heilversuchen in der medizinischen Diagnostik, Berlin 1990.

Hengstenberg N., Die hypothetische Einwilligung im Strafrecht, Berlin-Heidelberg 2013.

Hirsch H.-J. [w:] B. Jähnke, H. Laufhütte, W. Odersky (red.), Strafgesetzbuch. Leipziger Kommentar, t. 16, Berlin 2005, s. 151-165.

Hochmayr G., Karalne uszkodzenie ciała w Niemczech i Austrii. Zaskakujace rozbieżności, [w:] E. Hryniewicz, M. Małolepszy (red.), Karne aspekty spowodowania uszczerbku na zdrowiu w prawie niemieckim, polskim i austriackim, Poznań 2013, s. 17-30.

Jędrzejewski Z., Bezprawność jako element przestępności czynu. Studium na temat struktury przestepstwa, Warszawa 2009. 
Jordan A.-D., Zur strafrechtlichen Zulässigkeit placebokontrollierter Terapiestudien, Frankfurt am Main 1988.

Jürgens O., Die Beschränkung der strafrechtlichen Haftung für ärztliche Behandlungsfehler, Frankfurt am Main 2005.

Kaczmarek T., O kontratypach raz jeszcze, „Państwo i Prawo” 2009, z. 7, s. 91-99.

Kaufmann A., Die eigenmächtige Heilbehandlung, "Zeitschrift für die gesamte Strafrechtswissenschaft" 1961, nr 3, s. 341-384.

Kędziora R., Odpowiedzialność karna lekarza w związu z wykonywaniem czynności medycznych, Warszawa 2009.

Krey V., M. Heinrich, Strafrecht, besonderer Teil, t. 1, Stuttgart 2008.

Kubiak R., Kontratyp dozwolonego eksperymentu w świetle teorii kolizji dóbr i opłacalności społecznej, „Państwo i Prawo” 2005, z. 12, s. 64-69.

Kühl K., M. Heger, Strafgesetzbuch. Kommentar, München 2014.

Lilie H. [w:] B. Jähnke, H. Laufhütte, W. Odersky (red.), Strafgesetzbuch. Leipziger Kommentar, t. 16, Berlin 2005, s. 5-50.

Liszewska A., Odpowiedzialność karna za błąd w sztuce lekarskiej, Kraków 1998.

Loose A., Strafrechtliche Grenzen ärztlicher Behandlung und Forschung, Berlin 2003.

Marek A., Prawo karne, Warszawa 2011.

Maurach R., F.C. Schroeder, M. Maiwald, Strafrecht. Besonderer Teil, t. 1, Heidelberg 2009.

Mozgawa M. [w:] M. Mozgawa (red.), Prawo karne materialne. Część ogólna, Warszawa 2016, s. 257, 299-300.

Najda J., Z problematyki legalności zabiegów lekarskich na tle okoliczności wyłączajacych bezprawność czynu, „Przegląd Prawa i Administracji” 1995, t. 32, s. 59-67.

Niese W., Ein Beitrag zur Lehre vom ärztlichen Heileingriff, [w:] P. Bockelmann, W. Gallas (red.), Festschrift für Eberhard Schmidt zum 70. Geburtstag, Göttingen 1961, s. 364-382.

Oswald K., Heilversuch, Humanexperiment und Arzneimittelforschung. Eine systematische Einordnung humanmedizinischer Verschuchsbehandlung aus strafrechtlicher Sicht, [w:] C. Roxin, U. Schroth (red.), Handbuch des Medizinstrafrechts, Stuttgart i in. 2010, s. 669-728.

Piórkowska-Flieger J., M. Szwarczyk, Warunki dopuszczalności zabiegu leczniczego i eksperymentu medycznego w świetle nowej ustawy o zawodzie lekarza, "Rzeszowskie Zeszyty Naukowe. Prawo - Ekonomia” 1998, t. 23, s. 147-155.

Plebanek E., Materialne określenie przestępstwa, Warszawa 2009.

Pohl Ł., Prawo karne. Wykład części ogólnej, Warszawa 2015.

Reniger R., Strafrecht. Besonderer Teil. Delikte gegen die Person und die Allgemeinheit, München 2012.

Roxin C., Strafrecht. Allegmeiner Teil, t. 1. Grundlagen. Der Aufbau der Verbrechenslehre, München 2006. 
Safjan M., Prawo do ochrony życia prywatnego, [w:] L. Wiśniewski (red.), Podstawowe prawa jednostki $i$ ich sądowa ochrona, Warszawa 1997, s. 120-132.

Schönke A., H. Schröder, Strafgesetzbuch. Kommentar, München 1991.

Schroth U., Ärztliches Handeln und strafrechtlicher Maßstab. Medizinische Eingriffe ohne und mit Einwilligung, ohne und mit Indikation, [w:] C. Roxin, U. Schroth (red.), Handbuch des Medizinstrafrechts, Stuttgart i in. 2010, s. 21-50.

Schwalm G., Zu einigen ungelösten Strafrechtsproblemen, [w:] P. Bockelmann (red.), Festschrift für Karl Engisch zum 70. Geburtstag, Frankfurt am Main 1969, s. 548-560.

Seiterle S., Hipotetyczna zgoda pacjenta na zabieg medyczny w niemieckim prawie karnym - skuteczny środek ograniczenia odpowiedzialności karnej, [w:] E. Hryniewicz, M. Małolepszy (red.), Karne aspekty spowodowania uszczerbku na zdrowiu w prawie niemieckim, polskim i austriackim, Poznań 2013, s. 115-127.

Sroka T., Odpowiedzialność karna za niewłaściwe leczenie. Problematyka obiektywnego przypisania skutku, Warszawa 2013.

Stefański R.A., Prawo karne materialne. Część ogólna, Warszawa 2008.

Stooss C., Chirurgische Operation und ärztliche Behandlung. Eine strafrechtliche Studie, Berlin 1898.

Stooss C., Operativer Eingriff und Körprerverletzung, "Zeitschrift für Schweizer Strafrecht" 1893, t. 6, s. 53-61 [przedruk w: A. Eser, A. Künschner (red.), Recht und Medizin, Darmstadt 1990, s. 55-64].

Śliwiński S., Polskie prawo karne materialne. Część ogólna, Warszawa 1946.

Śliwowski J., Prawo karne, Warszawa 1979.

Tag B., Der Körperverletzungstatbestand im Spannungsfeld zwischen Patientenautonomie und Lex artis, Berlin-Heidelberg 2000.

Ulsenheimer K. [w:] K. Ulsenheimer, E. Biermann, R.W. Bock, Arztstrafrecht in der Praxis, Heidelberg 2015, s. 173-191, 352-376.

Warylewski J.J., Prawo karne. Część ogólna, Warszawa 2015.

Welzel H., Das Deutsche Strafrecht. Eine systematische Darstellung, Berlin 1969 [przedruk: Berlin 1989].

Wnukiewicz-Kozłowska A., Eksperyment medyczny na organizmie ludzkim w prawie międzynarodowym i europejskim, Warszawa 2004.

Wolter W., Nauka o przestępstwie, Warszawa 1973.

Wróbel W., A. Zoll, Polskie prawo karne. Część ogólna, Kraków 2010.

Zgoliński I., I. Zduński, Okoliczności wyłączające bezprawność. Zarys problematyki, Bydgoszcz 2012.

Złotek A., Charakter prawny zabiegu leczniczego - zarys problemu, "Czasopismo Prawa Karnego i Nauk Penalnych" 2010, nr 2, s. 51-62.

Zoll A., Odpowiedzialność karna za niepowodzenie w leczeniu, Warszawa 1988.

Zoll A., Zaniechanie leczenia - aspekty prawne, "Prawo i Medycyna” 2000, nr 5, s. 31-38. 


\section{THE DISPUTE ABOUT THE GROUNDS FOR THE LEGALITY OF THERAPEUTIC INTERVENTION FROM THE PERSPECTIVE OF GERMAN DOCTRINE AND JUDICATURE}

\section{Sum mary}

The German discussion on the grounds of the legality of therapeutic intervention is essentially focused, as in Poland, around the question of whether such an intervention fulfils the statutory elements of a prohibited act. The affirmative answer is provided by the conception referred to as the Rechtfertigungslösung, while the conception called Tatbestandslösung responds negatively to this question. The first of these positions, represented for more than a century by German jurisdiction and part of the doctrine, is based on the assumption that therapeutic intervention violating the integrity of the body fulfils the statutory elements of the criminal act of $\S 2231$ P.C., regardless of its healing purpose or effect and compliance with the rules of art by the doctor. The legality of such an intervention requires the existence of a circumstance excluding unlawfulness (Rechtfertigungsgrund), which is the valid consent of the patient. The second of the concepts mentioned above assumes - with some differences in specific issues - that therapeutic intervention resulting from medical indications and carried out lege artis does not fulfil the statutory elements of the crime of bodily harm. Some supporters of Tatbestandslösung make this assessment independent of the consent of the patient, but some require consent, recognizing it as an exclusion of the statutory element of a prohibited act.

The title dispute is to a large extent conditioned by the lack of a separate basis in German law for the criminal protection of the right of the patient to self-determination and seeking it in § 223 P.C. The fundamental subject of the presented discussion is, however, the question of whether to include in the legal assessment the side and unavoidable ailments for the human organism, inevitably occasioned by therapeutic intervention.

Key words: criminal law, medical law, therapeutic intervention, legality of therapeutic intervention, justification

\section{СПОР О ЗАКОННОСТИ ТЕРАПЕВТИЧЕСКОГО ВМЕШАТЕЛЬСТВА С ТОЧКИ ЗРЕНИЯ НЕМЕЦКОЙ ДОКТРИНЫ И СУДЕБНОЙ СИСТЕМЫ}

\section{Резиме}

Немецкая дискуссия о законности медицинского вмешательства сосредоточена, как и в Польше, вокруг вопроса о том, исчерпывает ли такое вмешательство суть запрещенного акта. Положительный ответ дает концепция 
Rechtfertigungslösung, а концепция Tatbestandslösung отвечает на этот вопрос отрицательно. Первая из этих концепций, представленная в течение более чем столетия немецким прецедентным правом и частью доктрины, основана на предположении, что медицинское вмешательство, нарушающее физическую неприкосновенность, исчерпывает законодательную сущность запрещенного телесного повреждения согласно § 2231 уголовного кодекса, независимо от его терапевтического назначения или эффекта, и от сохранения правил искусства доктором. Законность такого вмешательства требует наличия обстоятельства, исключающего незаконность (Rechtfertigungsgrund), которое является юридически действительным согласием пациента. Вторая из вышеупомянутых концепций допускает - с некоторыми различиями в некоторых вопросах - что вмешательство в лечение, обусловленное медицинскими показаниями и проведенная lege artis, не исчерпывает сути запрещенного акта из § 223 уголовного кодекса. Некоторые сторонники Tatbestandslösung делают вышеупомянутую оценку независимой от согласия пациента, а некоторые требуют согласия, признавая это обстоятельством, исключающим суть запрещенного действия.

Титульный спор в значительной степени обусловлен отсутствием отдельного основания в немецком законодательстве для уголовной защиты права пациента на самоопределение и обращения за ним в § 223 уголовного кодекса. Однако основной темой обсуждаемого обсуждения является вопрос о том, следует ли включать в правовую оценку побочные и неизбежные недуги для человеческого организма, неизбежно связанные с терапевтическим вмешательством.

Ключевые слова: уголовное право, медицинское право, лечение, законность обращения, исключение противоправности 